\title{
Pengaruh Penambahan Ekstrak Kayu Manis (Cinnamomum burmannii) terhadap Total Padatan, Kesegaran, dan Sensoris Susu Pasteurisasi
}

\author{
Ismiarti ${ }^{1 *}$ dan Nur Rohmat ${ }^{1}$ \\ ${ }^{1}$ Jurusan Peternakan, Fakultas Peternakan Universitas Darul Ulum Islamic Centre Sudirman GUPPI \\ Ungaran, Indonesia \\ *Korespondensi : ismiarti17@gmail.com
}

Artikel ini diterima (received): 16 Maret 2021; dinyatakan disetujui (accepted): 29 Mei 2021; terbit (published): 30 Mei 2021. Artikel ini dipublikasi secara daring pada https://ejournal.unib.ac.id/index.php/buletin_pt/index

\begin{abstract}
Abstrak
Pasteurisasi perlu dilakukan untuk menekan pertumbuhan bakteri patogen pada susu sebelum dikonsumsi. Penelitian ini bertujuan untuk mengkaji penambahan ekstrak kayu manis untuk meningkatkan kualitas susu pasteurisasi ditinjau dari total padatan, kesegaran, dan sensoris Sampel yang digunakan berupa susu murni yang diambil dari peternakan rakyat di Kabupaten Semarang, Jawa Tengah. Penelitian eksperimental ini menggunakan Rancangan Acak Lengkap (RAL) pola searah yang terdiri atas 4 perlakuan dan 5 kali ulangan. Perlakuan terdiri atas : PO = susu sapi pasteurisasi $+0 \%$ ekstrak kayu manis (kontrol), P1 = susu sapi pasteurisasi $+2 \%$ ekstrak kayu manis, $\mathrm{P} 2$ = susu sapi pasteurisasi $+4 \%$ ekstrak kayu manis, dan P3 = susu sapi pasteurisasi $+6 \%$ ekstrak kayu manis. Susu pasteurisasi diamati pada hari ke $0,3,7$, dan 14 untuk mengetahui total padatan dan kesegaran menggunakan uji alkohol $70 \%$, sedangkan uji sensoris dilakukan pada hari ke 0 . Pengujian sensoris dilakukan oleh 24 panelis agak terlatih. Hasil penelitian menunjukkan bahwa penambahan ekstrak kayu manis sampai dengan $6 \%$ tidak berpengaruh nyata terhadap total padatan dan kesegaran susu pasteurisasi. Total padatan P0, P1, dan P2 mengalami penurunan setelah penyimpanan sampai dengan 7 hari namun masih berada di kisaran normal, sedangkan P3 dibawah standar. Total padatan dari semua perlakuan berada di bawah standar setelah disimpan 14 hari. Kesegaran susu mulai menurun setelah disimpan 3 hari dan di hari ke 14, susu pasteurisasi sudah mengalami kerusakan. Penambahan ekstrak kayu manis berpengaruh sangat nyata terhadap warna dan rasa $(P<0,01)$ susu sapi pasteurisasi. Kesimpulannya, penambahan esktrak kayu manis dengan level berbeda mampu mempertahankan kualitas susu dan meningkatkan kualitas sensoris, namun tidak memperpanjang masa simpan.
\end{abstract}

Kata kunci: kayu manis, pasteurisasi, susu.

\section{Pendahuluan}

Ternak unggas merupakan ternak yang dapat dibudidayakan untuk tujuan produksi sebagai penghasil pangan sumber protein hewani bagi masyarakat dan memiliki nilai ekonomis bagi manusia yang memeliharanya. Jenis ternak unggas yang memberikan keuntungan antara lain yaitu ayam

Kebutuhan susu masyarakat Indonesia sebagian disuplai dari peternakan rakyat. Suranindyah et al. (2015) menyatakan bahwa peternak sapi perah skala rakyat dikelola secara tradisional sehingga memiliki kualitas lebih rendah dibandingkan setelah penerapan manajemen pemerahan yang lebih baik. Kualitas susu sapi sangat dipengaruhi oleh higienitas dan sanitasi yang diterapkan. Standar Nasional Indonesia (SNI) 3141.1:2011 mensyaratkan total mikrobia susu sapi segar maksimal $1 \times 10^{6} \mathrm{CFU} /$ $\mathrm{ml}$, hasil uji alkohol $70 \%$ negatif, dan tidak mengalami perubahan sifat organoleptik (warna, bau, rasa, dan kekentalan). Oleh karena itu, diperlukan adanya prosesing untuk menekan jumlah mikrobia pada susu sebelum 
dikonsumsi. Pasteurisasi merupakan cara pengolahan susu yang bertujuan untuk mempertahankan mutu dan keamanan susu dengan mengunakan cara pemanasan baik secara low temperature long time (LTLT) dengan suhu $63^{\circ} \mathrm{C}$ selama 30 menit maupun high temperature short time (HTST) dengan suhu $72^{\circ} \mathrm{C}$ selama 15 detik (Wardana, 2012). Susu pasteurisasi di Indonesia rata-rata memiliki masa simpan relatif singkat yaitu 5-7 hari (Kristanti, 2017), sehingga diperlukan penambahan bahan lain yang berpotensi memperpanjang masa simpan susu sekaligus meningkatkan kualitas baik secara fisik, kimia, mikrobiologis, maupun sensoris.

Antioksidan merupakan senyawa yang bisa menghambat berbagai jenis perubahan pada susu seperti perubahan warna, aroma, tekstur, dan perubahan nilai gizi (Thomas dan Duethi, 2001). Penelitian penambahan bahan-bahan sumber antioksidan telah banyak dilakukan terutama pada susu. Penambahan ekstrak florotanin asal rumput laut cokelat pada susu dengan level $0 \%$; 0,25\%; dan 0,50\% tidak berpengaruh nyata terhadap $\mathrm{pH}$ dan komposisi kimia, namun berpengaruh nyata terhadap aktivitas antioksidan dan komposisi kimia (Mugozin dan Husni, 2019). Darma et al. (2015) melaporkan bahwa penambahan ekstrak kulit manggis sampai dengan level $4 \%$ tidak mempengaruhi nilai $\mathrm{pH}$, aroma, dan rasa susu, namun berpengaruh terhadap kadar asam laktat, aktivitas antibakteri, dan kesukaan. Penelitian lain yang telah dilakukan oleh Maryana et al. (2016) dilaporkan bahwa penggunaan ekstrak daun binahong berpengaruh terhadap citarasa manis dan sepat pada susu pasteurisasi.

Bahan lain yang memungkinkan untuk meningkatkan kualitas susu pasteurisasi yaitu kayu manis. Kayu manis merupakan salah satu sumber antioksidan dengan kandungan utama dan terbesar yaitu sinamaldehid sebesar $92,0 \%$ (Pratiwi et al., 2015). Penambahan ekstrak kayu manis diharapkan mampu meningkatkan mutu susu sapi pasteurisasi.

\section{Bahan dan Metode}

Bahan yang digunakan dalam penelitian ini berupa susu murni yang diambil dari peternakan rakyat di Kabupaten Semarang, Jawa Tengah; kayu manis; akuades; dan alkohol $70 \%$. Alat yang digunakan terdiri kompor, panci, pengaduk kayu, gelas beker, tabung reaksi, timbangan analitik, botol timbang, desikator, $\mathrm{pH}$ meter, termometer, botol plastik, dan refrigerator. Pengujian sifat sensoris melibatkan 24 orang panelis agak terlatih.

\section{Rancangan Penelitian}

Parameter yang diamati yaitu total padatan, kesegaran, dan sifat sensoris. Desain penelitian menggunakan Rancangan Acak Lengkap pola searah yang terdiri atas P0 (kontrol), P1 (penambahan 2\% ekstrak kayu manis), P2 (penambahan $4 \%$ ekstrak kayu manis), dan P3 (penambahan $6 \%$ ekstrak kayu manis). Sampel disimpan pada refrigerator dengan kisaran suhu $4-8^{\circ} \mathrm{C}$ dan dilakukan pengukuran total padatan dan kesegaran pada $0,3,7$, dan 14 hari. Setiap perlakuan diulang sebanyak 5 kali. Data total padatan diuji lanjut menggunakan Duncan's Multiple Range Test (DMRT) dan kesegaran dianalisis secara deskriptif. Pengujian sifat sensori dilakukan pada sampel 0 hari. Data sifat sensoris diuji menggunakan Kruskal Wallis dan Mann Whitney.

\section{Pembuatan Ekstrak Kayu Manis}

Kayu manis dijemur di bawah sinar matahari selama tiga (3) hari sekitar pukul 10.00-15. 00 WIB sehingga dihasilkan kayu manis yang kering. Kayu manis kering kemudian dihaluskan menggunakan blender dan diayak dengan ayakan plastik berukuran 40 mesh sehingga diperoleh 100 gram kayu manis bubuk. Sebanyak 100 gram bubuk kayu manis dilarutkan dalam $1500 \mathrm{ml}$ akuades. Pemanasan dilakukan selama 15 menit pada suhu $100^{\circ} \mathrm{C}$ (Xu dan Lee, 2004 dengan modifikasi).

\section{Pasteurisasi}

Metode HTST diterapkan pada penelitian ini. Susu dipanaskan mencapai suhu $72^{\circ} \mathrm{C}$ selama 15 detik di atas air panas sambil diaduk sehingga panasnya merata. Susu didinginkan mencapai suhu ruang kemudian dimasukkan ke dalam wadah. Masing-masing susu dalam wadah diberi perlakuan berupa penambahan ekstrak kayu manis dengan level $0 \%(\mathrm{PO}), 2 \%(\mathrm{P} 1), 4 \%(\mathrm{P} 2)$, dan $6 \%(\mathrm{P} 4)$ kemudian disimpan selama $0,3,7$, dan 14 hari. 


\section{Pengujian Total Padatan}

Botol timbang dipanaskan di dalam oven selama 1 jam pada suhu $105^{\circ} \mathrm{C}$, kemudian di masukkan ke dalam desikator selama 1 jam dan ditimbang $(X)$. Sampel ditimbang kurang lebih 1,0 gram $(Y)$ di dalam botol timbang. Botol timbang berisi sampel dimasukan oven bersuhu $105^{\circ} \mathrm{C}$ selama $12 \mathrm{jam}$, lalu didinginkan dalam desikator selama 1 jam dan kemudian ditimbang (Z). Pengovenan dan penimbangan dilakukan hingga mencapai bobot konstan. Total padatan diukur dengan mengurangkan $100 \%$ dengan kadar air sampel. Kadar air dan total padatan dihitung dengan rumus sebagai berikut:

$$
\text { Kadar air }=\frac{(X+Y)-Z}{Y} \times 100 \%
$$

Keterangan :

$\mathrm{X}=$ berat botol timbang setelah dioven (g)

$\mathrm{Y}=$ berat sampel susu fermentasi ( $\mathrm{g}$ )

$Z$ = berat botol timbang + susu fermentasi setelah dioven $(\mathrm{g})$

Total padatan $=100 \%-$ kadar air $($ AOAC, 1975)

Pengujian Kesegaran (Uji Alkohol 70\%)

Uji alkohol dilakukan dengan cara menyiapkan sampel sebanyak $3 \mathrm{ml}$. Sampel ditambahkan alkohol 70\% kemudian dikocok perlahan hingga tercapur merata. Hasil kemudian diamati dengan melihat bagian permukaan bagian tabung reaksi. Uji alkohol positif ditandai dengan adanya butiran susu yang melekat pada dinding tabung reaksi. Uji alkohol negatif ditandai dengan tidak terlihatnya butiran yang melekat pada dinding tabung reaksi.

\section{Pengujian Sifat Sensoris}

Pengujian sensoris mengacu pada Soekarto (1985). Sensoris diuji oleh 24 panelis agak terlatih untuk mengukur tingkat kesukaan terhadap warna dan rasa sampel. Kriteria panelis agak terlatih yaitu mahasiswa peternakan yang sudah lulus mata kuliah Teknologi Hasil Tenak dan memiliki sensitifitas yang baik terhadap sensoris. Panelis menguji masing-masing sampel P0, P1, P2, dan P3 secara acak dengan kode yang berbeda.

\section{Hasil dan Pembahasan}

\section{Total Padatan}

Parameter kualitas dan harga susu susu salah satunya ditentukan oleh total padatan (Saputra, 2018). Penambahan ekstrak kayu manis sampai dengan level $6 \%$ tidak mempengaruhi total padatan $(P>0,05)$. Hal ini sesuai dengan penelitian Kusumawati et al. (2019), penambahan nanas madu dan ekstrak kayu manis tidak mempengaruhi kadar air yogurt susu kambing, yang artinya tidak berpengaruh juga terhadap total padatan. Berbeda dengan pendapat Ismawati et al. (2016) bahwa penambahan semakin banyak penambahan bit yang kaya antioksidan pada yogurt maka semakin meningkat total padatannya, karena bit mengandung gula yang relatif tinggi. Sementara itu, kayu manis memiliki kadar gula total sangat rendah yaitu 1,25\% (Hastuti, 2014). Hasil pengukuran total padatan secara lengkap tersaji pada Tabel 1. Pengamatan selama 14 hari menunjukkan penurunan total padatan mulai hari ke-3, 7, dan terendah pada hari ke-14. Total padatan susu pada pengamatan sampai dengan 7 hari masih berada di kisaran normal kecuali P3. $\mathrm{Hal}$ ini sesuai dengan pendapat Saputra (2018) bahwa total padatan susu yang normal berada di kisaran $10,82 \%$. Hasil pengamatan hari ke-14 didapatkan total padatan berada di bawah kisaran normal karena semakin lama penyimpanan, terjadi degradasi komponen nutrien susu akibat metabolisme mikrobia. Hal ini sesuai dengan pendapat Bayu et al. (2017) bahwa komponen total padatan salah satuny adalah laktosa yang merupakan substrat bagi mikrobia untuk melakukan metabolisme. Nurhajah et al. (2016) menyatakan bahwa total padatan susu terdiri atas lemak, protein, dan laktosa. Penyimpanan semakin lama menyebabkan semakin menurunnya kandungan nutrien susu pasteurisasi sehingga menurunkan total padatan

\section{Kesegaran}

Uji alkohol secara luas digunakan untuk menguji kesegaran susu secara mudah dan praktis (Nurliyani et al., 2015). Hasil uji alkohol secara lengkap tersaji pada Tabel 2. 
Tabel 1. Rerata Total Padatan Susu Sapi Pasteurisasi dengan Level Penambahan Ekstrak Kayu Manis yang Berbeda Selama Pengamatan

\begin{tabular}{lcccc}
\hline \multirow{2}{*}{ Hari } & \multicolumn{4}{c}{ Perlakuan } \\
\cline { 2 - 5 } & P0 & P1 & P2 & P3 \\
\hline 0 & $12,53 \pm 0,12$ & $12,03 \pm 0,19$ & $12,55 \pm 0,27$ & $13,93 \pm 2,57$ \\
3 & $12,23 \pm 1,29$ & $11,36 \pm 0,08$ & $11,36 \pm 0,34$ & $11,4 \pm 0,68$ \\
7 & $11,67 \pm 0,46$ & $11,23 \pm 0,07$ & $11,3 \pm 0,20$ & $10,75 \pm 0,51$ \\
14 & $10,4 \pm 1,56$ & $10,18 \pm 0,68$ & $10,55 \pm 0,76$ & $9,87 \pm 0,38$ \\
\hline
\end{tabular}

Tabel 2. Hasil Uji Alkohol Susu Sapi Pasteurisasi dengan Level Penambahan Ekstrak Kayu Manis Yang Berbeda Selama Pengamatan

\begin{tabular}{llllll}
\hline \multirow{2}{*}{ Parameter } & \multirow{3}{*}{ Kode } & \multicolumn{5}{c}{ Hari ke } \\
\cline { 2 - 6 } & POU1 & - & - & +++ & +++ \\
& POU2 & - & + & + & +++ \\
& POU3 & - & - & + & +++ \\
& POU4 & - & + & + & +++ \\
& POU5 & - & ++ & + & +++ \\
& P1U1 & - & - & +++ & +++ \\
& P1U2 & - & + & + & +++ \\
& P1U3 & - & + & + & +++ \\
& P1U4 & - & - & + & +++ \\
& P1U5 & - & ++ & - & +++ \\
P2U1 & - & ++ & + & +++ \\
P2U2 & - & - & + & +++ \\
P2U3 & - & - & + & +++ \\
P2U4 & - & - & + & +++ \\
P2U5 & - & + & + & +++ \\
P3U1 & - & + & + & +++ \\
P3U2 & - & - & + & +++ \\
P3U3 & - & - & + & +++ \\
P3U4 & - & + & + & +++ \\
P3U5 & - & + & + & +++ \\
\hline
\end{tabular}

Hasil penelitian menunjukkan bahwa pada setiap perlakuan di hari 0 hasil uji alkohol negatif, artinya penambahan ekstrak kayu manis sampai dengan $6 \%$ tidak mempengaruhi kesegaran susu. Pengamatan hari ke-3 mulai ada sampel yang menunjukkan uji alkohol positif baik P0, P1, P2, maupun P3. Hasil positif secara keseluruhan terjadi pada pengaamatan hari ke14. Hal ini sejalan dengan pendapat Umar et al. (2014) bahwa susu pasteurisasi mengalami kerusakan sejalan dengan lama waktu penyimpanan pada refrigerator ditinjau dari nilai pH dan uji reduktase. Habibah (2011) menyatakan bahwa semakin lama penyimpanan susu menyebabkan terjadinya perkembangan bakeri sehingga susu menjadi asam dan rusak. Uji alkohol positif ditandai dengan timbulnya butiran pada dinding tabung reaksi karena kestabilan koloidal protein susu bergantung pada selubung yang menyelimuti kasein.
Penambahan alkohol 70\% menjadikan selubung di sekitar kasein terikat oleh alkohol sehingga kasein saling melekat dan timbul endapan (Siirtola, 2000; Jaman et al., 2013). Penelitian Jaman et al. (2013) uji alkohol positif disebabkan susu telah mengalami pengasaman akibat bakteri asam laktat yang memfermentasi laktosa sehingga ikatan kasein berkurang dan kasein timbul sebagai butiran-butiran saat pengujian alkohol. Pengamatan hari ke-14 diasumsikan susu sudah rusak karena uji alkohol positif di semua perlakuan dan ulangan.

\section{Sifat sensoris}

Warna. Hasil uji sensoris warna susu pasteurisasi dengan penambahan kayu manis menunjukan hasil berpengaruh sangat nyata $(P<0.01)$ yang diuji oleh 24 panelis. Hasil uji lanjut menunjukan penambahan ekstrak kayu manis mempengaruhi warna susu pasteurisasi. Ranking uji sensoris warna dan rasa tersaji pada Tabel 3. Warna susu pasteruisasi dengan penambahan kayu manis perlakuan PO berbeda sangat nyata terhadap semua perlakuan; perlakuan P1 berbeda sangat nyata dengan P3; sedangkan $\mathrm{P} 1$ tidak berpengaruh nyata dengan P2; P2 tidak berbeda nyata dengan P3. Susu pasteruisasi yang ditambahkan dengan kayu manis mengalami perubahan warna. Hasil penelitian menunjukkan bahwa penerimaan konsumen terhadap warna semakin menurun seiring penambahan level kayu manis yang ditambahkan. Hal ini sesuai dengan penelitian Mugozin dan Husni (2019), panelis lebih menyukai warna susu komersial (kontrol) dibanding susu dengan penambahan rumput laut cokelat. Hastuti (2016) menyatakan bahwa perubahan warna kuning kecoklatan ini disebabkan adanya kandungan sinamaldehid pada kayu manis, sehingga semakin banyak level 
Tabel 3. Ranking Uji Sensoris Susu Sapi Pasteurisasi dengan Level Penambahan Ekstrak Kayu Manis yang Berbeda

\begin{tabular}{lcccc}
\hline \multirow{2}{*}{ Parameter } & \multicolumn{3}{c}{ Perlakuan } & P2 \\
\cline { 2 - 5 } & P0 & P1 & P3 \\
\hline Warna & $79,15^{\mathrm{a}}$ & $50,27^{\mathrm{b}}$ & $41,42^{\mathrm{bc}}$ & $23,17^{\mathrm{c}}$ \\
Rasa & $79,94^{\mathrm{a}}$ & $50,25^{\mathrm{b}}$ & $40,77^{\mathrm{bc}}$ & $23,04^{\mathrm{c}}$ \\
\hline
\end{tabular}

kayu manis yang ditambahakan menyebabkan warna susu pasteurisasi semakin gelap.

Rasa. Hasil uji sensoris rasa susu pasteurisasi dengan penambahan kayu manis menunjukan hasil berpengaruh sangat nyata $(P<0.01)$ yang diuji oleh 24 panelis. Hasil uji lanjut menunjukan bahwa penambahan kayu manis mempengaruhi rasa susu. Rasa susu pasteruisasi dengan penambahan kayu manis perlakuan PO berbeda nyata dengan semua perlakuan; $\mathrm{P} 1$ berpengaruh sangat nyata dengan P3; sedangkan P1 tidak berpengaruh nyata dengan P2; P2 tidak berpengaruh nyata dengan P3. Penambahan kayu manis pada susu pasteruisasi belum terlalu banyak diterapkan pada susu. Berdasar hasil penelitian, penerimaan konsumen terhadap susu pasteurisasi cenderung menurun seiring peningkatan level ekstrak kayu manis. Menurut Ozdal et al. (2013), terdapat perubahan rasa yang tidak diinginkan akibat interaksi protein dengan senyawa fenolik. Hal ini sesuai dengan penelitian Mugozin dan Husni (2019) bahwa terjadi penurunan tingkat kesukaan terhadap rasa susu yang ditambah florotanin dari rumput laut cokelat yang mengindikasikan adanya hubungan antar keduanya. Penambahan kayu manis pada susu pasteruisasi sangatlah bagus menurut Hariana (2008) karena peran minyak atsiri eugenol, sinamaldehide, tanin, kalsium oksalat, yang menyebabkan rasa manis pedas pada bubuk kayu manis. Sutarno dan Atmowidjojo (2001) menyatakan bahwa kayu manis dimanfaatkan untuk campuran pangan terutama cake dan jamu karena memiliki aroma harum dan rasa yang manis.

\section{Kesimpulan}

Penambahan ekstrak kayu manis tidak berpengaruh terhadap total padatan dan kesegaran susu sapi pasteurisasi namun berpengaruh terhadap sifat sensoris warna dan rasa. Penyimpanan suhu dingin menyebabkan penurunan total padatan dan kesegaran susu berdasar uji alkohol.

\section{Daftar Pustaka}

AOAC. 1975. Official Method of Analysis. 12th ed. Association of Official Analytical Chemists. Washington DC.

Bayu, M. K., H. Rizqiati., dan Nurwantoro. 2017. Analisis Total Padatan Terlarut, Keasaman, Kadar lemak, dan Tingkat Viskositas Pada Kefir Optima Dengan Lama Fermentasi Yang Berbeda. Jurnal Teknologi Pangan. 1(2):3338.

Darma, R. Malaka, dan F. Maruddin. 2015. Karakterstik dan Sifat Daya Hambat Escherichia coli Dengan Penambahan Ekstrak Kulit Manggis (Garcinia mangostana L.) Pada Susu Pasteurisasi. Jurnal Sains dan Teknologi. 15(3):278-283.

Hariana, A. 2008. Tumbuhan Obat dan Khasiatnya. Penebar Swadaya. Jakarta.

Hastuti, A. M. 2014. Pengaruh Penambahan Kayu Manis Terhadap Aktivitas Antioksidan Dan Kadar Gula Total Minuman Fungsional Secang Dan Daun Stevia Sebagai Alternatif Minuman Bagi Penderita Diabetes Melitus Tipe 2. Journal of Nutrition College. 3(3):362369.

Habibah. 2011. Pengaruh lama asteurisasi dan lama penyimpanan terhadap kualitas air susu sapi perah Friesian Holstein. Bioscientiae. 8(1):1-8.

Ismawati, N., Nurwantoro, dan Y. B. Pramono. 2016. Nilai pH, Total Padatan Terlarut, dan Sifat Sensoris Yoghurt dengan Penmabahan Ekstrak Bit (Beta vulgaris L.) Jurnal Aplikasi Teknologi Pangan. 5(3):89-93.

Jaman, M. F. V., I. K. Suada., dan I. P. Sampurna. 2013. Kualitas Susu Kambing Peranakan Etawa Selama Penyimpanan Suhu Ruang Ditinjau Dari Rasa, Ph, Dan Uji Alkohol. Indonesia Medicus Veterinus. 2(5)469-478.

Kristanti, N. D. 2017. Daya Simpan Susu Pasteurisasi Ditinjau Dari Kualitas Mikroba Termodurik dan Kualitas Kimia. Jurnal IImu Dan Teknologi Hasil Ternak. 12(1):1-7. 
Kusumawati, I., R. Purwanti, dan D. N. Afifah. 2019. Analisis Kandungan Gizi dan Aktivitas Antioksidan Pada Yoghurt Dengan Penambahan Nanas Madu (Anans cosomus Mer.) dan Ekstrak Kayu Manis (Cinnamomum burmanni). Jurnal of Nutrition College. 8(4):196-206.

Maryana, D., R. Malaka., dan F. Maruddin. 2016. Karakteristik Fisiko-Kimia dan Organoleptik Susu Pasteurisasi Dengan Penambahan Ekstrak Daun Binahong (Anredera cordifolia (Ten) Steenis) dan Sukrosa. Jurnal Sains dan Teknologi. 16(2):107-112.

Mugozin, A. dan A. Husni. 2019. Pengaruh Penambahan Ekstrak Florotanin Dari Sargassum sp. Pada Susu Segar Terhadap Aktivitas Antioksidan dan Tingkat Penerimaan Konsumen. JPHPI. 22(3):562572.

Nurhajah, A., A. Purnomoadi, D. W. Harjanti. 2016. Hubungan Antara Konsumsi Serat Kasar Dan Lemak Kasar Dengan Kadar Total Solid dan Lemak Susu Kambing Peranakan Ettawa. Agripet 16(1):1-8.

Nurliyani, Y. Suranindyah., dan P. Pertiwi. 2015. Quality And Emulsion Stability Of Milk From Ettawah Crossed Bred Goat During Frozen Storage. Procedia Food Science. 3:142-149.

Ozdal, T., E. Capanoglu, dan F. Altay. 2013. A Review on Protein-Phenolic Interactions And Associated Changes. Food Research International. 51(2013):954-970.

Pratiwi, S. U. T., E. L. Lagendijk, S. D. Wert, R. Idroes, T. Hertiani, C. V. D Hondel. 2015. Effect of Cinnamomum burmannii Nees Ex B1. and Massoia aromatic Becc. Essential Oils on Planktonic Growth and Biofilm Formation of Pseudomonas aeruginosa And
Staphylococcus Aureus In Vitro. International Journal Of Applied Research In Natural Product. 8(2):1-13.

Saputra, F. T. 2018. Evaluasi Total Solid Susu Segar Peternak Tawang Agro Berdsarkan Standard Nasional Indonesia. Jurnal Ternak Tropika. 19(1):22-26.

Siirtola, T. V. A. 2000. Journal of Establishment of Regional Reference Center for Milk Processing and Marketing . www. Fao . org / ag / AGAlnfo / Subjects / en / dairy / quality_chain .html. Diakses pada 10 Februari 2021.

Suranindyah, Y., E. wahyuni, S. Bintara., dan G. Purbaya. 2015. The Effect Of Improving Sanitation Prior To Milking On Milk Quality Of Dairy Cow In Farmer Group. Procedia Food Science. 3:150-155.

Standar Nasional Indonesia. 2011. SNI 3141.1:2011 tentang Susu Segar Bagian 1 : Sapi. Jakarta.

Sutarno H. dan S. Atmowidjojo. 2001. Tantangan Pengembangan dan Fakta Jenis Tanaman Rempah. Yayasan Prosea Indonesia. Bogor.

Thomas, J. dan P.P. Duethi. 2001. Cinnamon Handbook of Herbs and Spices.CRC Press. New York.

Umar, Razali, dan A. Novita. 2014. Derajat Keasaman dan Angka Reduktase Susu Sapi Pasteurisasi Dengan Lama Penyimpanan Yang Berbeda. Jurnal Medika Veterinaria. 8(1):43-46.

Wardana, A. S. 2012. Teknologi Pengolahan Susu. Fakultas Teknologi Pertanian Universitas Slamet Riyadi. Surakarta.

$\mathrm{Xu}, \mathrm{H}$ dan S. F. Lee. 2004. The Antibacterial Principle of Caesalpania sappan. Phytother Res. 18:647-651. 